\title{
한국 시민사회의 개발재원 현황
}

\section{목 차}

I. 서론

II. 국제사회 시민사회의 개발재원 현황

III. 한국 시민사회의 개발재원 현황

$\mathrm{IV}$. 결론

\section{I. 서론}

국제사회에서 시민사회는 제 1,2 차 세계대전의 과정에서 전쟁 피해자를 돕는 구호활동을 중심으로 국제개발협력 활동을 시작했다. 1950 70년대에 걸쳐 개발NGO를 중심으로 시민사회는 구호사업에서 개발사업으로 중심을 옮기며 개도국의 발전을 지원했다. 그 후 1980 년대와 1990 년대를 거치며 시민사회와 공여국 정부 간 재정지원을 내용으로 하는 파트너십이 제도화되었으며, 시민사회는 점차 중요한 국제개발협력 행위자로 자리매김 했다(Lewis et al 2009, 16-17). 2008 년 가나 아크라에서 개최된 '제3차 원조효과성고위급회의'의 결과문서인 '아크라행동선언(Accra Agenda for Action, AAA)'은 시민사회단체(Civil Society Organization, CSO)를 '독립적인 개발행위자(independent development actor)'로 그 중요성을 공식적으로 인정했다. ${ }^{12)}$ 그리고 현재 많은 양자· 다자간 원조기관들은 $\mathrm{NGO}$ 를 정부 원조기관과는 다른 특성을 가진 개발협력의 중요한 파트너로 인정하며 국제개발목표의 효과적인 달성을 위해 다양한 방식으로 협력하고 있다 (손혁상 외 2011, 112-130).

1) 이 글에서 $\mathrm{CSO}$ 와 $\mathrm{NGO}$ 가 혼재되어 사용되는데, $\mathrm{CSO}$ 는 개발NGO와 시민단체, 여성단체, 사회적 기업, 비영 리단체 및 대학과 같은 시민사회내의 다양한 구성원을 포괄하는 의미의 표현으로 사용된다.

2) 월드뱅크. 2008. 아크라행동선언.http://siteresources.worldbank.org/ACCRAEXT/ Resources/47007901217425866038/AAA-4- SEPTEMBER-FINAL-16h00.pdt.(검색일: 2014. 2. 6.) 
한국 정부는 1980년대 후반과 1990년대 초반에 국제개발협력을 본격적으로 시작했으며, 한국 시민사회는 전통적으로 통일, 인권, 민주화, 경제정의, 노동, 여성 및 환경 등 주로 국내의 이슈에 집중된 활동을 전개해왔고, 1990 대 들어 국제개발협력에 본격적으로 참여하기 시작했다. 구체적으로 보면 1990년대 초, 중반기에는 주로 해외 선교활동을 수행하던 개신교를 기반으로 하는 단체나 한국 전쟁이후 한국에서 구호 - 개발사업을 수행했던 외국민간원조단체(Foreign Voluntary Agency) 들이 전환된 개발 $\mathrm{NGO}$ 들이 시민사회 국제개발협력의 중심에 있었다(한국NPO공동회의 2013 22 26). ${ }^{3)}$ 그리고 1990년대 중, 후반 들어 경제개발협력기구(The Organization for Economic $\mathrm{Co}$-operation and Development, 이하 $\mathrm{OECD}$ )가입 등 국제사회에서 지위가 상승한 한국의 상황에 맞추어 출범한 개발NGO들이 국제개발협력에 본격 참여하기 시작했다. ${ }^{4)}$ 2000년대에는 아프가니스탄 및 이라크 전쟁, 서남아시아 쓰나미, 아이티 지진 및 최근의 필리핀 태풍 피해 지원의 과정에서 많은 개발NGO들이 인도적 지원 사업을 수행하며 국제개발협력에 참여했다. 그리고 2011 년 부산 세계개발원조총회의 개최 이후 한국 사회에서 국제개발협력에 대한 인식이 제고되면서 전통적으로 국제개발협력 사업을 수행하던 개발 $\mathrm{NGO}$ 들 외에 여성단체, 환경단체, 인권단체, 사회적 기업, 대학, 비영리단체(Non-Profit Orgnization, 이하 NPO), 각종 협회 등 시민사회의 다양한 주체들이 국제개발협력에 참여하고 있다.

국제개발협력 사업을 수행하는 CSO에 대한 정부의 지원도 지속적으로 증대했다. 1995년 CSO에 재정을 지원하는 프로그램을 시작한 한국국제협력단(Korea International Cooperation Agency, 이하 코이카)이 대표적이다. 그리고 2000년대 들어 안전행정부(이하 안행부)나, 보건복지부 산하기관인 한국국제보건의료재단 등이 $\mathrm{CSO}$ 의 국제개발협력 사업을 제도적으로 재정 지원하는 프로그램을 시작했다. 이러한 경향은 민간에서도 확대됐다. 2000년대 이후 사회복지공동모금회와 삼성꿈장학재단 같은 민간재단들이, 그리고 각종 대기업들이 사회공헌 차원에서 $\mathrm{CSO}$ 들의 국제개발협력 사업에 대한 재정지원을 확대해 나갔다. 작은 규모이지만 지방자치단체들도 꾸준히 $\mathrm{CSO}$ 의 국제개발협력사업에 재정을 지원했다. 개신교와 가톨릭, 불교, 원불교 등의 많은 종교기관들과 각종 기관들 또한 직, 간접적으로 $\mathrm{CSO}$ 의 국제개발협력 사업에 많은 재정을 지원했다. 그리고 마지막으로 개발 $\mathrm{NGO}$ 들을 중심으로 하는 많은 $\mathrm{CSO}$ 들이 1 대 1 결연프로그램과 같은 각종 모금 프로그램들을 개발해 많은 시민들로부터 재정을 확보하고 있다. 이같이 현재 국제개발협력에 참여하는 $\mathrm{CSO}$ 에 대한 재정지원을 $\mathrm{CSO}$ 의 '개발재원'으로 규정하면 이는 크게 정부 및 산하기관, 지방자치단체, 민간재단, 기업, (종교)기관 그리고 CSO 자체 모금으로 구분될 수 있다.

국제개발협력에 참여하는 $\mathrm{CSO}$ 들의 활동이 확대되고 이를 지원하는 재정지원이 증대하는 가운데, $\mathrm{CSO}$ 개발재원의 종류와 규모를 정확하게 파악하려는 시도는 매우 부족했다. 이는 정부가 공적개발원조 (Official Development Assistance, 이하 ODA)의 규모를 매년 체계적 시스템을 통해 집계하고 $\mathrm{OECD}$ 에 보고하는 것과는 달리 $\mathrm{CSO}$ 는 특성상 공식적이고 총괄적인 개발재원 집계 시스템이 없기

3) 1990 년대 초반기 개신교선교 활동을 기반으로 국제개발협력을 시작한 단체의 대표적인 사례는 한국 기아대 책기구이고, 외국민간원조단체가 전환한 대표적인 단체는 월드비전이다.

4) 이 시기에 변환된 국제적인 지위에 맞는 역할을 해야 한다는 목적을 가지고 설립된 대표적인 단체는 지구촌 나눔운동, 코피온 등이 있다. 
때문이다. 따라서 2014년 현재 국제개발협력에 참여하는 한국의 $\mathrm{CSO}$ 에 대한 개발재원의 종류와 규모는 어떠한가? 라는 질문에 대해 대답을 하는 것은 쉽지 않다. 단지 국제개발협력에 참여하는 $\mathrm{CSO}$ 들의 협의체인 국제개발협력민간협의회(Korea NGO Council for Overseas Development Cooperation, 이하 $\mathrm{KCOC}$ )가 2 년에 1 회씩 발간하는 '한국국제개발CSO 편람'을 통해서 개발재원의 종류와 규모를 대략적으로 파악할 수 있을 정도였다.

이상의 배경 하에 본 연구는 국제개발협력에 참여하는 한국 $\mathrm{CSO}$ 들의 개발재원의 종류와 규모를 밝히는 것을 목적으로 진행된다. 구체적으로는 국제개발협력에 참여하는 $\mathrm{CSO}$ 들의 개발재원의 종류를 객관적 파악가능성을 기준으로 정부(및 산하기관), 지방자치단체(이하 지자체), 민간재단, $\mathrm{CSO}$ 자체로 구분하고 홈페이지, 연간보고서 및 중앙정부기관, 정보공개청구 등의 방법을 활용하여 재원규모를 파악했다.

그런데 분명히 밝힐 것은 $\mathrm{CSO}$ 의 개발재원 종류를 완벽하게 밝히는 데에는 여러 측면에서 한계가 있다는 점이다. 앞서 언급한 바와 같이 $\mathrm{ODA}$ 와는 다르게 $\mathrm{CSO}$ 의 개발재원은 공식적인 집계시스템이 없다는 점이 가장 큰 한계이다. 그리고 코이카와 한국국제보건의료재단 및 몇몇 민간재단들을 제외하고는 다수의 중앙정부기관 및 지자체, 기업, 민간재단 등은 $\mathrm{CSO}$ 의 국제개발협력 사업에 국한되어 재정을 지원하는 프로그램을 운영하지 않는다. 특별히 기업이 $\mathrm{CSO}$ 의 국제개발협력 사업을 지원하는 것에 관한 정보를 확보하는 것은 매우 어렵다. 구체적으로, 전국경제인연합회(이하 전경련)가 매년 회원기업들의 사회공헌활동을 정리해서 발간하는 '기업 · 기업재단사회공헌백서'는 회원기업들의 ‘해외사회공헌' 금액 규모는 밝히지만 이 지원금이 전부 $\mathrm{CSO}$ 를 통해 집행됐다고 보기는 어렵다. 전경련 회원기업들의 사회공헌방식은 '기부형태'와'직접사업형태'로 구분되는데 둘 다 CSO와 협력하는 방식이 가능하나 '기업 · 기업재단사회공헌백서'는 어느 규모의 사회공헌금액이 CSO를 통해 개도국에 지원되는지 구체적으로 밝히지는 않는다. 또한 몇몇 기업들이 사회공헌백서나 홈페이지를 통해 소수의 $\mathrm{CSO}$ 의 국제개발협력 사업에 대한 지원을 밝히는데, 이를 통해 전체적인 규모나 추세를 파악하기는 어렵다. 이러한 이유로 본 연구는 기업이나 기업재단이 CSO의 국제개발협력사업을 지원하는 재원규모를 밝히는 것은 제외한다. 종교 및 사회기관 등의 CSO 국제개발협력 사업지원 규모도 공식적인 집계 시스템이 없기 때문에 밝히기 어렵다.

그리고 본 연구에서 밝히는 $\mathrm{CSO}$ 의 개발재원의 종류와 규모는 공개된 정보만을 근거로 제시되며, 이는 실제와는 차이가 있을 수 있음을 밝힌다. 마지막으로 $\mathrm{CSO}$ 를 통해 지원된 재정을 분야별, 국가별, 사업방식별로 분석하는 것도 $\mathrm{CSO}$ 의 개발재원 분석에 있어 매우 의미가 있는 접근법이나, 기관별로 공개하는 정보의 차이로 인해 이러한 분석은 한계가 있다. 따라서 CSO 개발재원의 종류와 규모만을 밝히는 것이 본 연구의 범위이다. 


\section{II. 국제사회 시민사회의 개발재원 현황}

국제사회에서 시민사회의 개발재원을 파악하는데 있어 가장 광범위하게 사용되는 것은 $\mathrm{OECD}$ $\mathrm{DAC}$ 회원국들의 ODA 지원이다. 이는 매년 OECD가 발표하는 통계를 통해 파악할 수 있는데 아래 〈표1〉과 같이 크게 두 가지로 정리된다. 첫째는 DAC회원국의 자국NGO 및 기타 민간주체(private bodies)들에 대한 재정지원이고, 다른 하나는 국제NGO에 대한 재정지원이다. 전자는 2003년에서 2012년까지 10년간 USD 10억에서 USD 20억 사이의 규모를 보인다. 둘째는 DAC 회원국이 국제 $\mathrm{NGO}$ 들에게 재정을 지원한 내용으로 2003년에서 2012년까지 USD 3억에서 USD 8억 사이의 규모를 보인다. 이 두 내용을 합치면 2012년에는 약 USD 23억이다.

〈표1〉2003 2012년 OECD DAC 회원국의 CSO 재정지원 규모

\begin{tabular}{c|r|r|r}
\hline 년도 & $\begin{array}{c}\text { 자국NGO와 기타 민간주체에 } \\
\text { 대한 재정지원(USD 백만) }\end{array}$ & $\begin{array}{c}\text { 국제NGO에 대한 재정지원 } \\
\text { (USD 백만) }\end{array}$ & $\begin{array}{c}\text { 합계 } \\
\text { (USD 백만) }\end{array}$ \\
\hline 2003 & $1,489.58$ & 374.88 & $1,864.46$ \\
\hline 2004 & $1,793.69$ & 592.69 & $2,386.38$ \\
\hline 2005 & $1,783.31$ & 595.86 & $2,379.17$ \\
\hline 2006 & $2,042.39$ & 640.2 & $2,682.59$ \\
\hline 2007 & $2,183.77$ & 537.65 & $2,721.42$ \\
\hline 2008 & $2,517.12$ & 478.65 & $2,995.77$ \\
\hline 2009 & $2,131.37$ & 498.98 & $2,630.35$ \\
\hline 2010 & $1,568.89$ & 782.07 & $2,350.96$ \\
\hline 2011 & $1,473.89$ & 832.1 & $2,305.99$ \\
\hline 2012 & $1,481.63$ & 871.21 & $2,352.84$ \\
\hline 합계 & $18,465.64$ & $6,204.29$ & $24,669.93$ \\
\hline
\end{tabular}

출처: http://stats.oecd.org/Index.aspx?DataSetCode=TABLE1 내용을 필자가 재구성함.

그런데 자국 $\mathrm{NGO}$ 에 대한 공여국의 $\mathrm{ODA}$ 지원은 성격에 따라 크게 두 가지 방식으로 구분된다. 첫째는 'NGO에 대한 지원(aid to NGO)'으로 CSO가 권한과 책임을 가진 자체사업에 정부가 재정을 지원 하는 방식이다. 둘째는 'NGO를 통한 지원(aid through NGO)'으로 정부가 발굴하고 책임을 가진 $\mathrm{ODA}$ 사업을 $\mathrm{CSO}$ 가 실행하는 경우이다(OECD 2011, 54). 후자는 한국적 맥락에서 본다면 $\mathrm{ODA}$ 사업의 실행주체인 PMC(Project Managing Consultancy)를 CSO가 하는 경우다.

〈표2〉는 2009년 OECD DAC 회원국가들의 CSO 재정지원 규모를 'NGO에 대한 지원'과 'NGO를 통한 지원'으로 구분해 제시한다. 이를 보면 대다수의 국가들이 'NGO에 대한 지원'보다 'NGO를 통한 지원‘에 더욱 큰 규모의 ODA를 집행함을 알 수 있다. 네덜란드, 벨기에, 일본, 한국 등 4개 국가만이 'NGO에 대한 지원' 방식의 규모가 크다. 
〈표2〉 2009년 OECD DAC회원국의 NGO에 대한(to) 및 통한(through) 원조 규모 비교

(단위: USD 백만)

\begin{tabular}{|c|c|c|c|c|}
\hline 순위 & 국가 명 & $\begin{array}{l}\text { NGO에 대한(to)원조, } \\
\text { (양자간 원조 대비 비중) }\end{array}$ & $\begin{array}{l}\mathrm{NGO} \text { 를 통한(through)원조, } \\
\text { (양자간 원조 대비 비중) }\end{array}$ & $\begin{array}{c}\text { 합계, } \\
\text { (양자간원조 대비 비중) }\end{array}$ \\
\hline 1 & 미국 & $0,(0 \%)$ & $6,239,(24 \%)$ & $6,239,(24 \%)$ \\
\hline 2 & 네덜란드 & $1,027,(21 \%)$ & $453,(9 \%)$ & $1,480,(30 \%)$ \\
\hline 3 & 영국 & $323,(4 \%)$ & $745,(10 \%)$ & $1,068,(14 \%)$ \\
\hline 4 & EU & $0,(0 \%)$ & $1,455,(11 \%)$ & $1,455,(11 \%)$ \\
\hline 5 & 독일 & $0,(0 \%)$ & $993,(2 \%)$ & $993,(12 \%)$ \\
\hline 6 & 스페인 & $20,(0 \%)$ & 922, (19\%) & $942,(20 \%)$ \\
\hline 7 & 노르웨이 & $0,(0 \%)$ & $863,(27 \%)$ & $863,(27 \%)$ \\
\hline 8 & 스웨덴 & 137, (5\%) & $640,(21 \%)$ & $777,(26 \%)$ \\
\hline 9 & 캐나다 & $55,(2 \%)$ & 585, (18\%) & 639, (20\%) \\
\hline 10 & 스위스 & $140,(8 \%)$ & $340,(19 \%)$ & $480,(27 \%)$ \\
\hline 11 & 벨기에 & $181,(11 \%)$ & $155,(9 \%)$ & $336,(20 \%)$ \\
\hline 12 & 일본 & $240,(2 \%)$ & $81,(1 \%)$ & $321,(2 \%)$ \\
\hline 13 & 아일랜드 & $102,(5 \%)$ & $153,(22 \%)$ & $255,(37 \%)$ \\
\hline 14 & 호주 & $58,(3 \%)$ & $195,(8 \%)$ & $253,(11 \%)$ \\
\hline 15 & 덴마크 & $55,(3 \%)$ & $126,(8 \%)$ & $181,(11 \%)$ \\
\hline 16 & 핀란드 & $3,(0 \%)$ & $173,(22 \%)$ & $176,(22 \%)$ \\
\hline 17 & 프랑스 & $12,(0 \%)$ & $106,(1 \%)$ & $118,(1 \%)$ \\
\hline 18 & 이탈리아 & $8,(1 \%)$ & $118,(11 \%)$ & $126,(12 \%)$ \\
\hline 19 & 룩셈부르크 & 8, (3\%) & $77 .(29 \%)$ & $84,(32 \%)$ \\
\hline 20 & 오스트리아 & $2,(0 \%)$ & 67, (13\%) & $69,(13 \%)$ \\
\hline 21 & 뉴질랜드 & $24,(11 \%)$ & $25,(11 \%)$ & 49, (22\%) \\
\hline 22 & 대한민국 & $8,(1 \%)$ & $4,(1 \%)$ & $11,(2 \%)$ \\
\hline 23 & 포르투갈 & 4, (1\%) & $5,(1 \%)$ & $8,(3 \%)$ \\
\hline 24 & 그리스 & $0,(0 \%)$ & $5,(2 \%)$ & $5,(2 \%)$ \\
\hline \multicolumn{2}{|r|}{ 합계 } & 2,406 & 14,523 & 16,929 \\
\hline
\end{tabular}

출처: OECD. 2011. "How DAC members work with civil society organizations", Paris: OECD.에서 필자가 재구성

국제사회에서 공여국 정부 외 $\mathrm{CSO}$ 에 대한 주요 개발재원으로는 다자간기구가 있다. 대표적인 곳이 세계은행(World Bank)이나 아시아개발은행(Asian Development Bank)과 같은 다자간개발은행 (Multilateral Development Bank, MDB)과 UN 산하기관들이다. 그리고 빌앤멀린다게이츠재단 (Bill and Malinda Gates Foundation)같은 민간재단들도 $\mathrm{CSO}$ 들의 주요한 개발재원이다. 


\section{III. 한국 시민사회의 개발재원 현황}

국제개발협력에 참여하는 한국 $\mathrm{CSO}$ 의 개발재원의 종류는 I 장에서 밝힌 바와 같이 크게 여섯 가지이나 본장에서는 정보 확보가 가능한 네 종류의 개발재원을 중심으로 개발재원의 현황을 밝힌다. 첫째는 정부 및 산하기관이다. 정부 산하기관으로는 무상원조 수행기관인 코이카와 보건복지부 산하기관인 한국국제보건의료재단이 있고, 중앙정부기관으로는 $\mathrm{NGO}$ 사업에 대한 재정지원 프로그램을 운용하는 안행부가 있다. 둘째는 지방자치단체이다. 비록 규모는 작지만 많은 지방자치단체들이 $\mathrm{CSO}$ 의 국제개발협력 사업에 대해 재정을 지원한다. 셋째는 민간재단이다. 사회복지공동모금회와 삼성꿈장학재단은 $\mathrm{CSO}$ 의 국제개발협력 사업에 재정을 지원하는 대표적인 민간재단들이다. 넷째는 $\mathrm{CSO}$ 의 자체모금이다. 1 대 1 결연이나 개인후원자, 후원행사, 수익사업 등이 그 내용이다. 본 장에서는 상기의 네 가지 개발재원을 중심으로 규모를 밝히는 방식으로 한국 CSO 의 개발재원의 현황을 파악한다.

\section{1. 정부 및 산하기관}

\section{1) 정부산하기관}

(1) 코이카

코이카는 1995년 '민간단체지원사업’을 시작으로 $\mathrm{CSO}$ 의 국제개발협력 사업에 대해 본격적으로 재정을 지원했다. 이 프로그램으로 CSO에게 지원된 재정규모는 〈표3〉에서 볼 수 있듯이 1990 년대에는 3억원에서 6억원 사이였지만, 2001년에는 10억원 규모를, 2011년에는 100억원 규모를 넘었다. '민간단체지원사업'은 $\mathrm{OECD}$ 기준으로 보면 $\mathrm{NGO}$ 에 대한 지원(aid to $\mathrm{NGO}$ ) 로 $\mathrm{CSO}$ 의 자체사업에 코이카가 재정을 지원하는 성격을 가진다. 그런데 〈표3〉에서 제시하는 내용은 코이카에서 $\mathrm{CSO}$ 지원 사업을 전담하는 부서인 민관협력실이 수행하는 프로그램들만 포함한다. 2014년 2월을 기준으로 민관협력실이 수행하는 프로그램은 '시민사회협력프로그램 (국별민간단체지원사업, 민간단체발굴지원사업, 현지시민사회단체지원사업으로 구성됨)', '글로벌 사업회공헌사업', ‘역량강화프로그램', ‘국제이해증진사업, '대학과의파트너십사업' 5 개이다. 이 프로그램들 중 '시민사회협력프로그램'과 '역량강화프로그램'은 주로 개발 $\mathrm{NGO}$ 들을 대상으로 하고, '글로벌사회공헌사업’은 정부, $\mathrm{CSO}$, 기업 간의 협력을 내용으로 한다. 그리고 '국제이해증진사업'과 '대학과의파트너십사업'은 대학을 주된 파트너로 한다. 
〈표3〉1995 2012년 코이카의 CSO 재정지원 규모

\begin{tabular}{c|c}
\hline 년도 & 규모(백만원) \\
\hline 1995 & 489 \\
\hline 1996 & 539 \\
\hline 1997 & 619 \\
\hline 1998 & 328 \\
\hline 1999 & 426 \\
\hline 2000 & 618 \\
\hline 2001 & 1,018 \\
\hline 2002 & 1,734 \\
\hline 2003 & 7,933 \\
\hline 2004 & 1,502 \\
\hline 2005 & 2,837 \\
\hline 2006 & 2,726 \\
\hline 2007 & 2,633 \\
\hline 2008 & 7,201 \\
\hline 2009 & 6,957 \\
\hline 2010 & 9,100 \\
\hline 2011 & 16,440 \\
\hline 2012 & 30,939 \\
\hline 합계 & 94,039 \\
\hline
\end{tabular}

출처: 1995 2012년 코이카 연보의 내용을 필자가 재구성함.

〈그림1〉1995 2012년 코이카의 CSO 재정지원 규모의 변화

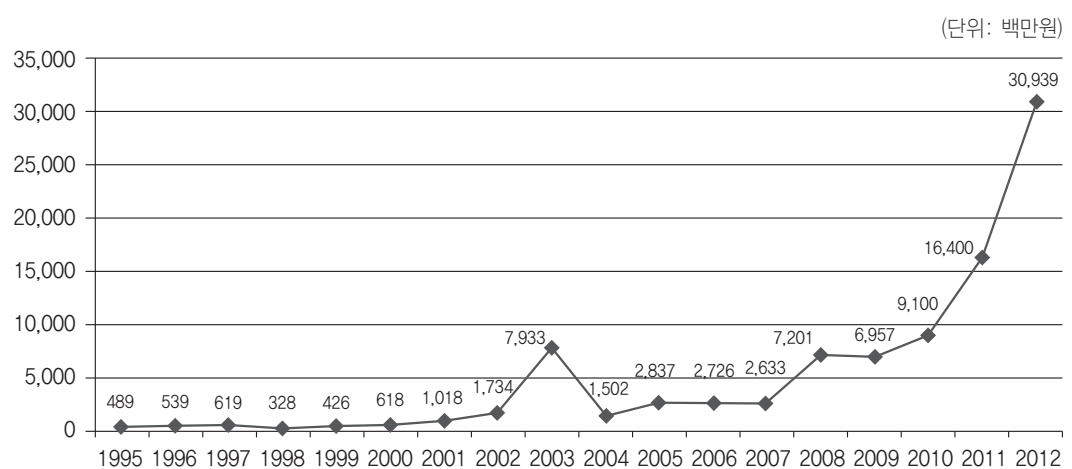

출처: 1995 2012년 코이카 연보의 내용을 필자가 재구성함. 
〈표3〉이 제시하는 내용에는 ' $\mathrm{NGO}$ 를 통한 지원(aid through NGO)' 방식 즉, 코이카의 PMC 사업에 CSO가 참여하는 사업의 재원규모는 포함되지 않는다. 〈표4〉는 2007년 이후 코이카 사업에 $\mathrm{PMC}$ 로 참여한 $\mathrm{CSO}$ 의 재원규모를 제시한다. 의료, 보건, 인구, 및 사회복지를 전문으로 하는 개발 $\mathrm{NGO}$ 나 협의체 및 에너지단체 등 총 13 개 단체가 약 87 억원의 $\mathrm{ODA}$ 를 $\mathrm{PMC}$ 로 집행했다. 서구 공여국과는 달리 아직 한국 $\mathrm{CSO}$ 들의 코이카 사업수행 규모가 매우 작음을 알 수 있다.

〈표4〉1995 2013년 코이카 사업에 CSO가 PMC로 참여한 사업의 재정규모5)

\begin{tabular}{c|c}
\hline 년도 & 규모(백만원) \\
\hline 2007 & 670 \\
\hline 2008 & 915 \\
\hline 2009 & 358 \\
\hline 2010 & 1,658 \\
\hline 2011 & 3,405 \\
\hline 2012 & 1,481 \\
\hline 2013 & 224 \\
\hline 합계 & 8,714 (6) \\
\hline
\end{tabular}

출처: 정보공개청구를 통해 코이카가 제공한 자료를 필자가 재구성함.

코이카는 2012년부터 CSO들의 인도적지원 사업을 지원하는 '인도적지원민관협력사업'프로그램을 진행하고 있다. 이는 코이카의 CSO 지원 사업 담당부서인 '민관협력실'이 아닌 '인도지원다자협력실' 이 주관하는 사업으로 그 규모는 〈표5〉와 같다.

〈표5〉 코이카 인도적지원민관협력사업을 통한 CSO 재정지원 규모

\begin{tabular}{c|c}
\hline 년도 & 규모 (백만원) \\
\hline 2012 & 1,155 \\
\hline 2013 & 1,803 \\
\hline 합계 & 2,958 \\
\hline
\end{tabular}

출처: 코이카에서 제공한 자료를 필자가 재구성함.

〈표6〉은 2004년부터 코이카가 월드프렌즈 $\mathrm{NGO봉사단} \mathrm{프로그램을} \mathrm{통해} \mathrm{CSO에} \mathrm{봉사단원을}$ 파견한 실적을 보여준다. 이를 보면 지속적으로 재정이 증대해서 2013년에는 약 63억에 달한다.

5) 이 표에서 제시하는 내용에서는 대학은 제외된다. 그 이유는 $\mathrm{PMC}$ 로 참여한 대학은 본연의 기능인 연구용역 에 초점이 맞추어져있는 경우가 많다. 대학이 개발사업을 수행하는 경우도 있는데 이 경우도 제외한다.

6) 2007 2013년의 재정지원을 백만원이하까지 총 집계하면 87억1천4백만원이다. 
〈표6〉 코이카가 월드프렌즈 NGO봉사단 프로그램을 지원한 재정 규모

\begin{tabular}{c|c}
\hline 년도 & 규모 (백만원) \\
\hline 2004 & 1,125 \\
\hline 2005 & 1,967 \\
\hline 2006 & 1,151 \\
\hline 2007 & 2,500 \\
\hline 2008 & 2,292 \\
\hline 2009 & 2,140 \\
\hline 2010 & 2,900 \\
\hline 2011 & 3,508 \\
\hline 2012 & 3,822 \\
\hline 2013 & 6,344 \\
\hline 합계 & $27,751^{7)}$ \\
\hline
\end{tabular}

출처: 코이카에서 제공한 자료를 필자가 재구성함.

〈표7〉은 코이카가 2008년부터 2012년까지 진행한 빈곤퇴치기여금으로 CSO를 지원한 재정의 규모이다. 5 년간의 총 금액은 약 191 억원이다.

〈표7〉 2008 2012년 코이카의 빈곤퇴치기여금을 통한 CSO지원 재정 규모

\begin{tabular}{c|c}
\hline 년도 & 규모 (백만원) \\
\hline 2008 & 1,810 \\
\hline 2009 & 2,648 \\
\hline 2010 & 4,815 \\
\hline 2011 & 4,628 \\
\hline 2012 & 5,277 \\
\hline 합계 & $19,180^{8)}$ \\
\hline
\end{tabular}

출처: 코이카에서 제공한 자료를 필자가 재구성함.

이상에서 기술한 바와 같이 코이카가 $\mathrm{CSO}$ 에 재정을 지원하는 경로는 민관협력사업, $\mathrm{PMC}$ 참여, 인도적지원사업, 월드프렌즈 $\mathrm{NGO봉사단,} \mathrm{빈곤퇴치기여금} \mathrm{다섯} \mathrm{가지로} \mathrm{구분된다.} 2012$ 년을 기준으로 이상의 다섯 경로를 통해 코이카가 $\mathrm{CSO}$ 에 지원한 재정규모는 〈표8>과 같이 약 426 백억원의 규모이다.

7) 2004 2013년의 재정지원을 백만원이하까지 총 집계하면 277억5천 1 백만원이다.

8) 2008 2013년의 재정지원을 백만원이하까지 총 집계하면 191억8천만원이다. 
〈표8〉 2012년 코이카의 CSO 재정지원 규모

\begin{tabular}{c|c}
\hline 구분 & 2012년 (백만원) \\
\hline 민관협력 & 30,939 \\
\hline PMC 참여 & 1,481 \\
\hline 인도적지원 민관협력 & 1,155 \\
\hline 월드프렌즈 NGO봉사단 & 3,822 \\
\hline 빈곤퇴치기여금 & 5,277 \\
\hline 합계 & 42,674 \\
\hline
\end{tabular}

출처: 코이카에서 제공하거나 정보공개청구를 통해 확보한 자료를 필자가 재구성함.

\section{(2) 한국국제보건의료재단}

한국국제보건의료재단은 보건복지부 산하 특별법인으로 개도국을 포함한 외국, 북한, 재외동포 및 외국인근로자를 대상으로 보건의료지원사업을 수행하기 위해 2006년 설립된 기관이다. ${ }^{9}$ 한국국제보건의료재단은 2011년 개도국에서 보건의료사업을 수행하는 한국 $\mathrm{CSO}$ 들에 재정을 지원하는 '민관협력공모사업'을 시작했으며, 2013년까지 지원규모는 〈표9〉와 같다. 4년간 CSO 들에 지원된 재정규모는 총 약 18 억원이며 매년 10 억 미만의 재정을 $\mathrm{CSO}$ 에게 지원하고 있다. 이 기관의 $\mathrm{CSO}$ 지원규모는 코이카에 비해서는 매우 작으나 매년 점점 큰 폭으로 증가하고 있음을 알 수 있다. 또한 코이카 외에 $\mathrm{CSO}$ 의 국제개발협력 사업에 재정을 지원하는 유일한 정부 산하기관의 프로그램이며, 보건의료 분야에 특화됐다는 점에서 의미가 있다.

〈표9〉2011 2013년 한국국제보건의료재단의 민관협력공모사업의 규모

\begin{tabular}{c|c}
\hline 년도 & 규모 (백만원) \\
\hline 2010 & 484 \\
\hline 2011 & 23 \\
\hline 2012 & 883 \\
\hline 2013 & 483 \\
\hline 합계 & $1,874^{10)}$ \\
\hline
\end{tabular}

출처: 정보공개청구를 통해 한국국제보건의료재단에서 제공한 자료를 필자가 재구성함.

\footnotetext{
9) 한국국제보건의료재단. 2014. 소개 http://kofih.org/hboard3/bbs/board.php?bo_table=m01_s01 (검색일: 2014. 2. 7)

10) 2010 2013년의 재정지원을 백만원이하까지 총 집계하면 18억7천4백만원이다.
} 


\section{2) 중앙정부기관}

정부의 중앙정부기관들은 각 기관의 성격에 맞게 비영리민간단체들의 공익활동을 지원하는 프로그램을 운영하고 있다. 2011년 $\mathrm{KCOC}$ 편람은 중앙정부기관들 중 교육부, 보건복지부, 여성가족부, 외교부, 안전행정부 등이 $\mathrm{CSO}$ 의 국제개발협력 사업에 재정을 지원한다고 밝히고 있다 (국제개발협력민간협의회 2012, 23 24). 본 연구는 2000년 이후 이 기관들이 CSO의 국제개발협력 사업에 대해 재정을 지원한 내용을 홈페이지나 정보공개청구를 통해 확보했다. ${ }^{11)}$

\section{(1) 안전행정부}

안행부는 2000년 '비영리민간단체공익활동지원사업’을 시작해서 현재까지 다양한 분야의 CSO들의 사업에 대해 재정을 지원하고 있다. 2013년을 기준으로 보면 이 사업은 '취약계층복지와자원봉사 . 기부나눔확산', '국가안보 · 재난안전과사회통합' 등 몇 개의 주제를 정하고 그에 맞는 사업을 수행하는 $\mathrm{CSO}$ 들에게 재정을 지원하는 방식으로 추진된다. 이 사업의 주제 중 하나인 '글로벌협력및네트워크 구축'분야에서 많은 $\mathrm{CSO}$ 들이 국제개발협력 사업을 수행한다. 〈표10〉과 〈그림2〉의 내용은 2000년 부터 2013년 까지 진행된 '비영리민간단체공익사업’의 ‘글로벌협력및네트워크구축'분야에 선정되어 재정을 지원받은 $\mathrm{CSO}$ 의 사업 중 국제교류를 목적으로 하지 않고 개발서비스제공(service delivery) 성격의 사업에 대한 재정지원 규모를 정리한 것이다. ${ }^{22}$ 구체적으로 보면 2000년에서 2010년까지 재원의 규모는 1억원에서 4억원까지 이지만, 2011년에는 10억원을 넘었고 2013년에는 24억원에 이른다. 이는 2010 년을 전후로 우리 사회에서 국제개발협력에 대한 관심과 참여가 증대한 결과가 반영된 것으로 판단된다.

〈표10〉2000 2013년 안행부 ‘비영리민간단체공익활동지원사업’ 선정 사업 중 국제개발협력 사업의 규모

\begin{tabular}{c|c}
\hline 년도 & 규모 (백만원) \\
\hline 2000 & 120 \\
\hline 2001 & 240 \\
\hline 2002 & 210 \\
\hline 2003 & 270 \\
\hline 2004 & 246 \\
\hline 2005 & 246 \\
\hline 2006 & 293 \\
\hline 2007 & 118 \\
\hline
\end{tabular}

11) 교육부, 보건복지부, 여성가족부에 정보공개를 청구했으며 보건복지부가 제공한 자료만이 본 연구의취지에 맞으며, 여성가족부가 제공한 자료는 국제교류에 해당하는 내용이다. 교육부는 타 기관으로 이송했다. 안행 부의 경우는 필자가 직접 홈페이지에서 해당 자료를 확보했다.

12) 해외봉사단파견도 포함한다. 


\begin{tabular}{c|c}
\hline 년도 & 규모 (백만원) \\
\hline 2008 & 376 \\
\hline 2009 & 318 \\
\hline 2010 & 481 \\
\hline 2011 & 1,069 \\
\hline 2012 & 1,588 \\
\hline 2013 & 2,416 \\
\hline 합계 & 7,991 \\
\hline
\end{tabular}

출처: 안행부홈페잊hthp://www.mospa.go.kr/frt/bbs/type001/commonSelectBoardList.do?bbsld=BBSMSTR 000000000058 를 통해 확보한 자료를 필자가 재구성함.

〈그림2〉 2000 2013년 안행부 “비영리민간단체공익활동지원사업' 선정 사업 중 국제개발협력 사업의 규모

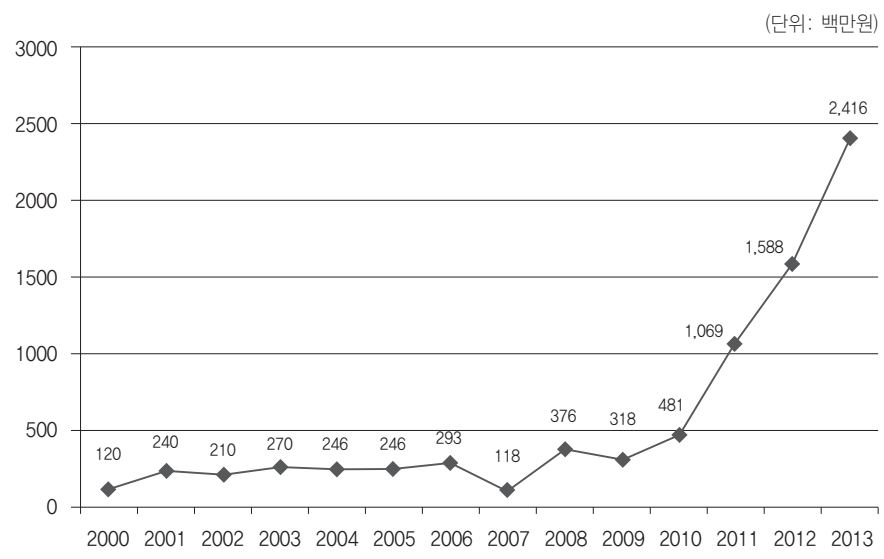

출처: 안행부홈페이지http://www.mospa.go.kr/frt/bbs/type001/commonSelectBoardList.do?bbsld=BBSMSTR_ 000000000058 를 통해 확보한 자료를 필자가 재구성함.

안행부의 CSO 국제개발협력 사업에 대한 재정지원은 규모면에서 코이카 보다 작지만, 다른 정부 및 산하기관의 지원보다는 그 규모와 역사 측면에서 상대적으로 비중이 크다. 그리고 2010년 이후 지원 규모도 꾸준히 증대하고 있어 $\mathrm{CSO}$ 의 안정적인 개발재원 역할을 한다고 판단된다.

\section{(2) 보건복지부}

보건복지부는 〈표11〉과 같이 의료전문NGO인 '(사)대한한방해외의료봉사단'의 국제개발협력 사업에 대해 2003년부터 지속적으로 재정을 지원하고 있다. 지난 11 년간 재정지원 규모는 22 억원이다. 
〈표11〉 2003 2013년 보건복지부의 CSO 재정지원 규모

\begin{tabular}{c|c}
\hline 년도 & 규모 (백만원) \\
\hline 2003 & 200 \\
\hline 2004 & 200 \\
\hline 2005 & 200 \\
\hline 2006 & 200 \\
\hline 2007 & 200 \\
\hline 2008 & 200 \\
\hline 2009 & 200 \\
\hline 2010 & 200 \\
\hline 2011 & 200 \\
\hline 2012 & 200 \\
\hline 2013 & 200 \\
\hline 합계 & 2,200 \\
\hline
\end{tabular}

출처 : 정보공개청구를 통해 보건복지부에서 제공한 자료를 필자가 재구성함.

\section{2) 지방자치단체}

전국의 많은 지자체들이 '비영리민간단체공익활동지원사업'을 운영하는데, 이를 통해 지원받는 $\mathrm{CSO}$ 의 사업들 중 소수지만 국제개발협력 사업이 있다. 본 연구는 전국의 9 개 도, 1 개 특별시 및 6 개 광역시에 $\mathrm{CSO}$ 의 국제개발협력 사업 지원 현황에 대해 정보공개청구를 했다. 그 결과 부산시와 충청남도 그리고 경기도만이 정보를 제공했다. ${ }^{13)}$

\section{(1) 경기도}

경기도는 〈표12〉와 같이 $\mathrm{CSO}$ 의 국제개발협력 사업에 대한 재정지원 내용을 제공했다. 이 내용을 구체적으로 살펴보면, 경기도는 2004년을 제외한 2003년에서 2013년까지 10년간 총 34억1천2 백만원을 개발NGO, 의료단체, 사회단체, 협회, 대학, 새마을단체 등 $\mathrm{CSO}$ 의 국제개발협력 사업에 지원했다.

13) 정보를 제공하지 않은 다른 지자체들 중 일부는 CSO의 국제개발협력 사업에 대한 재정지원이 실제 없는 것 으로 판단되지만, 몇몇 지자체들은 정보공개청구의 내용을 명확히 파악하지 못해 '정보없음'이라는 답변을 제시한 것으로 여겨진다. 충청남도가 제출한 자료는 본 연구의 범위와 거리가 있어 본문에서는 제외했다. 
〈표12〉 2003 2013년 경기도의 ODA 사업 중 CSO의 국제개발협력 사업에 대한 재정지원 규모

\begin{tabular}{c|c}
\hline 년도 & 규모 (백만원) \\
\hline 2003 & 150 \\
\hline 2005 & 542 \\
\hline 2006 & 230 \\
\hline 2007 & 208 \\
\hline 2008 & 328 \\
\hline 2009 & 176 \\
\hline 2010 & 155 \\
\hline 2011 & 416 \\
\hline 2012 & 441 \\
\hline 2013 & 766 \\
\hline 합계 & 3,412 \\
\hline
\end{tabular}

출처: 정보공개청구를 통해 보건복지부에서 제공한 자료를 필자가 재구성함.

경기도가 10 년간의 $\mathrm{CSO}$ 의 국제개발협력 사업에 대해 지원한 재정규모는 중앙정부기관인 안행부의 14 년간의 지원규모인 79 억9천 1 백만원의 약 $43 \%$ 에 해당한다. 이는 지자체로서는 작지 않은 규모로 국제개발협력에 대한 경기도의 관심을 파악할 수 있는 대목이다.

(2) 부산시

부산시가 정보공개청구에 응해 제출한 자료를 보면 〈표13〉과 같이 2009년부터 2013년까지 총 약 3 억원의 재정을 국제개발사업과 해외봉사단사업을 수행하는 부산시의 $\mathrm{CSO}$ 에 지원했다.

〈표13〉2009 2013년 부산시가 CSO의 국제개발협력 사업에 대한 재정지원 규모

\begin{tabular}{c|c}
\hline 년도 & 규모 (백만원) \\
\hline 2009 & 40 \\
\hline 2010 & 35 \\
\hline 2011 & 46 \\
\hline 2012 & 83 \\
\hline 2013 & 81 \\
\hline 합계 & 285 \\
\hline
\end{tabular}

출처: 정보공개청구를 통해 부산시에서 제공한 자료를 필자가 재구성함.

부산시가 지난 5 년간 $\mathrm{CSO}$ 의 국제개발협력 사업에 대해 지원한 재정규모는 상대적으로 같은 지자체인 경기도가 지난 5 년간 지원한 재정 규모인 19 억 5 천 4 백만원의 $14.6 \%$ 에 해당하는 작은 규모이다. 지자체간에도 $\mathrm{CSO}$ 의 국제개발협력 사업에 대한 관심과 여건에 차이가 있음을 알 수 있다. 


\section{3. 민간재단}

\section{1) 사회복지공동모금회}

사회복지공동모금회는 1999 년 설립된 전문 민간모금 및 배분기관인 사회복지법인으로 국내 아동 - 청소년, 노인, 여성·가족, 지역공동체들을 지원한다. ${ }^{14) ~ 〈 ㅍ ㅛ 14 〉 ㄴ ㅡ ㄴ ~ ㅅ ㅏ ㅎ ㅚ ㅂ ㅗ ㄱ ㅈ ㅣ ㄱ ㅗ ㅇ ㄷ ㅗ ㅇ ㅁ ㅗ ㄱ ㅡ ㅁ ㅎ ㅚ ㄱ ㅏ ~}$ 해외지원사업을 통해 2010년부터 2013년까지 CSO에 지원한 재정의 규모를 정리한 것인데, 2010 년 약 80억원 규모에서 2011년 이후 지속적으로 100 억원 이상의 규모를 유지하고 있다.

〈표14〉2010 2013년 사회복지공동모금회의 해외지원사업 재정 규모

\begin{tabular}{c|c}
\hline 년도 & 규모 (백만원) \\
\hline 2010 & 8,335 \\
\hline 2011 & 10,382 \\
\hline 2012 & 11,463 \\
\hline 2013 & 17,082 \\
\hline 합계 & 47,262 \\
\hline
\end{tabular}

출처: 사회복지공동모금회로부터 제공받은 자료를 필자가 재구성함.

〈표14〉가 보여주는 사회복지공동모금회의 해외지원사업 규모는 긴급구호를 제외한 매년 정기적으로 시행하는 $\mathrm{CSO}$ 지원 사업만 정리한 것이다. 실제 $\mathrm{CSO}$ 의 긴급구호사업을 지원하는 내용을 포함할 경우 규모는 더 커질 것으로 판단된다.

\section{2) 삼성꿈장학재단}

삼성꿈장학재단은 2006년 출범한 민간재단으로 국내외 저소득층 아동 - 청소년들의 교육을 지원하는 사업을 수행하고 있다. ${ }^{15)}$ 삼성꿈장학재단은 2007 년부터 개도국과 중국, 러시아, 멕시코 등지의 한인후손들의 교육을 지원하는 '글로벌꿈장학사업'과 '글로벌교육지원사업’을 수행하고 있다. 이 사업들은 대학과 한국 $\mathrm{CSO}$ 들에 재정을 지원하는 방식으로 추진되고 있으며, 2007년 이후 2013 년까지의 재정지원 규모는 〈표15〉와 같다. 사업은 2007년 약 1 억원을 넘는 규모로 시작했는데 지속적으로 2 4억원 규모를 유지하다가 2012년 약 5억원을 넘었다.

14) http://www.chest.or.kr/

15) 삼성꿈장학재단. 2014. 소개 http://www.sdream.or.kr/about/about01_01.jsp (검색일: 2014.2.5) 
〈표15〉2007 2013년 삼성꿈장학재단의 글로벌장학사업 재정 규모

\begin{tabular}{c|c}
\hline 년도 & 규모 (백만원) \\
\hline 2007 & 109 \\
\hline 2008 & 434 \\
\hline 2009 & 251 \\
\hline 2010 & 416 \\
\hline 2011 & 477 \\
\hline 2012 & 562 \\
\hline 합계 & 2,249 \\
\hline
\end{tabular}

출처: 삼성꿈장학재단 2007 2012년 연간보고서 내용을 필자가 재구성함.

삼성꿈장학재단의 글로벌장학사업은 $\mathrm{CSO}$ 와 대학의 교육개발 사업만을 지원한다는 특성을 가지고 있으며, 코이카와 안행부 및 사회복지공동모금회보다는 상대적으로 작은 규모를 보인다.

\section{CSO 자체모금}

국제개발협력 사업을 수행하는 $\mathrm{CSO}$ 들은 정부 및 산하기관, 기업, 민간재단에서 지원받는 것 외에도 상당부분의 재정을 자체적으로 모금한다. $\mathrm{CSO}$ 의 자체모금은 1 대 1 결연, 개인후원금, 모금행사, 수익사업 등 다양한 방식으로 이루어진다. 이러한 $\mathrm{CSO}$ 의 자체모금의 규모를 파악하는 것은 쉽지 않다. 정부의 $\mathrm{ODA}$ 규모 파악과 같은 공식적이고 체계화된 시스템이 없기 때문이다. 국제개발협력에 참여하는 $\mathrm{CSO}$ 의 자체모금 규모를 대략적으로나마 파악하는 것은 $\mathrm{KCOC}$ 의 편람을 통해 가능하다. 〈표16〉에서 제시하듯이 편람작성을 위한 조사에 응한 83개 CSO의 총 후원금 규모는 약 1 조원인데 이중 개인후원금이 약 3 천 9 백억원이고 기타수입이 약 3 천 1 백억원이다. 그리고 정부 지원금이 약 1 천 5 백억원이고 기업(기관)후원금이 약 1천 5 백억원이다.

\section{〈표16〉2011년 83개 CSO의 모금규모 현황}

\begin{tabular}{c|c|c|c|c|c}
\hline & $\begin{array}{c}\text { 개인후원금 } \\
\text { (백만원) }\end{array}$ & $\begin{array}{c}\text { 정부지원금 } \\
\text { (백만원) }\end{array}$ & $\begin{array}{c}\text { 기업(기관)후원금 } \\
\text { (백만원) }\end{array}$ & $\begin{array}{c}\text { 기타수입 } \\
\text { (백만원) }\end{array}$ & $\begin{array}{c}\text { 합계 } \\
\text { (백만원) }\end{array}$ \\
\hline 규모 & 392,363 & 158,894 & 152,180 & 311,825 & $1,015,262$ \\
\hline
\end{tabular}

출처: 국제개발협력민간협의회. 2012.한국국제개발협력CSO편람`서울: 국제개발협력민간협의회.

그런데〈표16〉에서 밝힌 2011년 83개 CSO의 모금액 약 1조원이 전부 국제개발협력 사업으로 집행되는 것은 아니다. 많은 $\mathrm{CSO}$ 들이 국내사업과 북한지원 사업을 같이 수행하기 때문이다. 따라서 이를 고려하고〈표17〉이 제시하는 87개 CSO의 국제개발협력 사업비 규모를 보아야 한다. 2011년 
87 개 CSO들은 현금 약 2천8백억 원 물자 약 3 백억원 총 약 3 천 2 백억원 규모의 재정을 국제개발협력 사업으로 집행했다. ${ }^{16)}$

〈표17〉 2011년 87개 CSO의 국제개발협력 사업비 규모 현황

\begin{tabular}{c|r|r|r}
\hline & 현금(백만원) & 물자(백만원) & 합계(백만원) \\
\hline 규모 & 286,828 & 33,698 & 320,526 \\
\hline
\end{tabular}

출처 : 국제개발협력민간협의회. 2012. "한국국제개발협력CSO편람』서울: 국제개발협력민간협의회

그런데 이 같은 규모의 $\mathrm{CSO}$ 국제개발협력 사업비에는 정부와 기업의 재정지원금과 1 대 1 결연, 개인후원금, 후원행사, 수익사업 등을 통한 CSO 자체모금이 합쳐져 있다. 따라서 $\mathrm{CSO}$ 의 자체모금을 통한 국제개발협력 사업비 규모를 정확히 파악하는 것은 어렵다. $\mathrm{CSO}$ 의 자체모금을 통한 국제개발협력 사업비 규모를 밝히는 것은 백여 개 이상의 $\mathrm{CSO}$ 들의 연간보고서를 분석해서 1 대 1 결연이나, 개인의 지정기탁과 같은 방식의 재원을 파악하는 방법이 있다. 그러나 이는 현실적으로 쉽지 않은 방법으로 차후 본격적인 연구를 통해 파악해야 할 것이다.

\section{IV. 결론}

지구촌에서 다양한 내용의 국제개발협력 사업을 수행하는 한국 $\mathrm{CSO}$ 에 대한 개발재원의 종류와 규모는 지속적으로 증대하고 있다. 본 연구는 그 동안 한국 $\mathrm{CSO}$ 의 개발재원의 종류와 규모에 대한 연구가 없었음에 착안해, 정보공개청구, 홈페이지 분석, 자료요청, 기존문헌 분석의 방식을 통해 개발재원의 종류와 규모를 대략적으로 밝혔고 이를 통해 다음의 세 가지 결과를 제시한다.

첫째, 한국의 $\mathrm{CSO}$ 개발재원의 규모는 정확하게 재정규모를 공개한 기관만을 기준으로 보면 〈표 18) 과 같이 2012년을 기준으로 약 57,894 억원 규모이다. ${ }^{17)}$

〈표18〉2012년 CSO개발재원의 종류별 규모

\begin{tabular}{l|c|r}
\hline \multicolumn{2}{c|}{ CSO 개발재원 종류 } & \multicolumn{2}{|c}{ 2012년 규모 (백만원) } \\
\hline \multirow{2}{*}{ 정부 산하기관 } & KOICA & 42,674 \\
\cline { 2 - 3 } & 한국국제보건의료재단 & 883 \\
\hline \multirow{2}{*}{ 중앙정부기관 } & 안행부 & 1,588 \\
\cline { 2 - 3 } & 보건복지부 & 200 \\
\hline
\end{tabular}

16) 이는 2011년 코이카의 ODA 집행규모인 4,518억원의 약 $71 \%$ 에 해당하는 규모이다.

17) 그러나 공개하지 않은 기관들의 내용을 합치면 더욱 규모는 더욱 클 것이라고 판단된다. 


\begin{tabular}{l|c|r}
\hline \multicolumn{2}{c|}{ CSO 개발재원 종류 } & \multicolumn{2}{|c}{ 2012년 규모 (백만원) } \\
\hline \multirow{2}{*}{ 지방자치단체 } & 경기도 & 441 \\
\cline { 2 - 3 } & 부산시 & 83 \\
\hline \multirow{2}{*}{ 민간재단 } & 사회복지공동모금회 & 11,463 \\
\cline { 2 - 3 } & 삼성꿈장학재단 & 562 \\
\hline & & 57,894 \\
\hline
\end{tabular}

출처: 정보공개청구, 홈페이지, 연간보고서등을 통해 확보한 자료를 필자가 재구성함.

둘째, 한국 $\mathrm{CSO}$ 의 개발재원은 크게 정부와 민간 그리고 $\mathrm{CSO}$ 자체모금으로 구분할 수있다. 이를 구체적으로 보면 정부차원에서는 코이카, 한국국제보건의료재단과 같은 정부산하기관과 안행부, 여성부와 같은 중앙정부기관 그리고 경기도와 부산시 같은 지자체가 있다. 그리고 민간차원에서는 사회복지공동모금회, 삼성꿈장학재단과 같은 민간재단과 정확한 규모를 밝히는 것은 어렵지만, 기업과 기업재단 및 종교단체 등의 기관이 있다. 마지막으로 $\mathrm{CSO}$ 의 자체모금은 후원금, 1 대 1 결연, 개인후원금, 후원행사, 수익사업 등이 있는 것으로 보인다.

셋째, 정확하게 파악된 한국 $\mathrm{CSO}$ 의 개발재원을 2012년 기준으로 규모가 큰순으로 정리해 보면 첫째는 코이카의 ODA 지원(426억7천4백만원)이고, 다음은 사회복지공동모금회의 해외지원사업 프로그램 (114억6천3백만원), 안행부의 비영리민간단체공익활동지원사업(15억8천8백만원), 한국국제보건 의료재단 민관협력공모사업(8억8천3백만원), 삼성꿈장학재단의 글로벌장학사업(5억6천2백만원), 경기도의 사업비지원(4억4천1백만원), 보건복지부(2억원)부산시(8천3백만원), 순이다. CSO에 대한 민간재단의 재정지원 규모가 중앙정부기관 및 지방자치단체에 비해 크다는 것을 알 수 있다. 그리고 정확한 파악은 어렵지만, $\mathrm{CSO}$ 의 자체모금이 다른 개발재원 보다 가장 규모가 클 것으로 추정된다.

최근 한국 시민사회에서 전통적인 개발행위자인 개발NGO 외에 대학, 비영리단체, 여성단체, 종교기반단체, 협동조합, 사회적 기업 등 다양한 $\mathrm{CSO}$ 들이 국제개발협력에 참여하고 있다. 또한 이들의 국제개발협력 사업에 재정을 지원하는 개발재원도 점차 다양해지고 있고 규모도 지속적으로 증대하고 있다. 그러나 $\mathrm{CSO}$ 의 개발재원을 정확히 파악하는 것은 정부 $\mathrm{ODA}$ 에 비해 매우 어려우며 정부, 학계, 연구기관 등 어느 누구도 정확히 파악하지 못하고 있다. $\mathrm{KCOC}$ 와 한국 $\mathrm{NPO}$ 공동회의 두 기관이 정기적으로 설문조사를 통해 집계하고 정리하는 것으로 유일하다. 그러나 이도 $\mathrm{CSO}$ 의 모든 개발재원을 완벽하게 파악하지는 못한다. 따라서 $\mathrm{CSO}$ 의 국제개발협력 사업에 재정을 지원하는 코이카 및 $\mathrm{KCOC}$, 학계, 연구기관 등 주요 관계자들이 적절한 방법론을 개발해서 정기적으로 $\mathrm{CSO}$ 개발재원의 종류와 규모의 현황과 변화 추이를 밝히는 것을 체계할 필요가 있다. 이러한 노력은 $\mathrm{CSO}$ 개발재원의 효율적 활용과 나아가 $\mathrm{CSO}$ 의 국제개발협력 사업의 효율성, 효과성 증대에 기여할 것으로 판단된다. 


\section{〈참고문헌〉}

\section{1. 국내문헌}

국제개발협력민간협의회. 2012『한국국제개발협력CSO편람』서울: 국제개발협력민간협의회 손혁상, 한재광, 박보기. 2011."국제개발협력에서의 정부-시민사회협력관계연구: OECD $\mathrm{DAC}$ 회원국의 $\mathrm{NGO}$ 지원정책 사례분석을 중심으로."국가전략』 제 17 권 4호 겨울. 한국NPO공동회의. 2013. 2011 한국개발복지NPO총람』서울: 한국NPO공동회의.

\section{2. 국외문헌}

Lewis, David and Nazneen Kanji. 2009. 『Non-Governmental Organizations and Development. $₫$ New York: Routledge.

OECD. 2011. ${ }^{\circledR}$ How DAC members work with civil society organizations.』Paris: OECD.

\section{3. 기타}

삼성꿈장학재단 2007 2012년 연간보고서.

한국국제협력단 1995 2012년 연보.

코이카, 경기도, 보건복지부, 충청남도, 부산시, 한국국제보건의료재단이 정보공개청구에 대해 제출한 자료.

사회복지공동모금회가 제공한 자료.

\section{4. 인터넷 자료}

사회복지공동모금회. 2014. 소개 http://www.chest.or.kr/ (검색일: 2014.2.5)

삼성꿈장학재단. 2014. 소개 http://www.sdream.or.kr/about/about01_01.jsp (검색일: 2014.2.5)

안행부. 2014.비영리민간단체공익지원사업.http://www.mospa.go.kr/frt/bbs/ type001/common SelectBoardList.do ?bbsId=BBSMSTR_000000000058 (검색 일: 2014.2.7). 
월드뱅크. 2008. 아크라행동선언.http://siteresources. worldbank. org/ACCRAEXT/

Resources/4700790-1217425866038/AAA-4-SEPTEMBER-FINAL-16h00.pdf.（검 색일: 2014.2.4.).

한국국제보건의료재단.2014.소개http://kofih.org/hboard3/bbs/board.php?bo_ table=m01_s 01. (검색일: 2014.2.7.)

OECD.2014.NGO지원규모 http://stats. oecd.org/Index.aspx?DataSetCode= TABLE 1 (검색일: 2014.2.5.) 